\title{
Minimizing carbon loss through integrated water resource management on peatland utilization in Pulau Burung, Riau, Indonesia
}

\author{
Nurul Ihsan Fawzi ${ }^{*}$, Annisa Noyara Rahmasary, and Ika Zahara Qurani \\ Tay Juhana Foundation, Jln. Rawa Bebek Utara No.26, Penjaringan, North Jakarta, 14440 Indonesia
}

\begin{abstract}
Sustainable utilization of peatland is required for balancing production and conservation efforts. On peatland, one of the main components to examine sustainability is understanding the carbon balance. This research was conducted in Pulau Burung, Riau, Indonesia, which has a long history of peatland utilization for agriculture. The sets of utilized data included historical data of water management on peatland represented by water table and subsidence rate, next to carbon density of peat soil. The results showed the function of integrated water resource management made the yearly average water table depth is 48 and $49 \mathrm{~cm}$ in 2018 and 2019, respectively. The range water table is between $31 \mathrm{~cm}$ to $72 \mathrm{~cm}$ due to season variability and crop requirement. Consequently, the rate of annual subsidence is averaging at $1.7 \mathrm{~cm}$ with cumulative subsidence in $32 \mathrm{yr}$ is $54.1 \mathrm{~cm}$. Since the water never drained since the establishment, the subsidence rate of the first five years is averaging only at $3.3 \mathrm{~cm} \mathrm{yr}^{-1}$. Low subsidence rates minimize annual carbon loss during the peatland utilization around (30 to 200) $\mathrm{Mg} \mathrm{CO}_{2} \mathrm{ha}^{-1} \mathrm{yr}^{-1}$. In $32 \mathrm{yr}$, the water management in peatland utilization in Pulau Burung has prevented $2000 \mathrm{Mg} \mathrm{CO}_{2}$ ha $^{-1}$ to $4925 \mathrm{Mg} \mathrm{CO}_{2}$ ha $^{-1}$ loss compared to other cultivated areas in peatland. Further, this paper discusses the practice that resulted in low emission of coconut agriculture in Pulau Burung as one of sustainability dimensions, which support the other sustainability aspects, that is the thriving local livelihood.
\end{abstract}

\section{Introduction}

Indonesia is the largest country with peatland expanses in the tropical area. It covers approximately eight percent of the country's land surface [1]. Peatland is an accumulated organic matter ecosystem under permanent fresh-water inundation [2]. The land plays important roles in the global ecosystem, including biodiversity conservation, water preservation, carbon pool and sequestration, timber and non-timber products, and balancing climate change. The carbon storage in peatland in Indonesia is estimated at around 25.8 -30.8 gigatons of carbon [3].

Despite its vital roles, the condition of the peatland ecosystem all over the world is deteriorating. Peatland degradation in Indonesia is mainly due to over-drainage in peat region conversion into agriculture, where the process requires drained soil for optimal growth $[4,5]$. Building canals as a system to drain peatland water has been widely practiced to support large-scale agriculture and plantations. Under natural conditions, peatland has a high water table which makes it fire-resistant. Peatland is like a sponge with a critical function to store water [6]. Over-drainage causes the soil organic layer of peat soil decomposed and leads to land subsidence.

The impact of over-drainage leads to at least five combinations of catastrophes - flood, drought, subsidence, wildfire, and huge carbon release. The function of storing water is disturbed which results in flooding during the rainy season. During the dry season, the drainage system removed its water storage function. This dry soil condition makes it vulnerable to wildfire, especially when the effect of the El Niño Southern Oscillation (ENSO) is stronger. The wildfire was responsible for 4037 to $14680 \mathrm{t}$ of carbon dioxide released per hectare $\left(\mathrm{Mg} \mathrm{CO}_{2} \mathrm{ha}^{-1}\right)$ [7, 8]. In peatland, there is a relationship between a low water table with a high subsidence rate [9]. The problem caused by the subsidence of peatland is also releasing greenhouse gases or carbon emission. Higher subsidence rate contributes to higher carbon emission [10-12].

On the other hand, peatland is increasingly important for economic development and livelihood. Peatland conversion for agriculture purposes is inevitable since demands for commodities and food resources keep rising. The growing number of the world population and shortage of food availability has contributed to ten percent of global undernourishment [13]. At the same time, in twenty years of observation (1992-2015), urban areas increased 38 million ha, from 33.2 to 71.3 million ha; where 24.3 million ha were converted from cropland areas [14]. 
Peatland is one of the suboptimal land types that is feasible to be an alternative for food production in the agricultural sector [15]. One of the crops that is produced in plantations in Indonesia's peatland is coconut. Demand for this commodity has risen to five-fold in the last decade. Coconut-based products are essential ingredients for local cuisines in the tropical regions. Coconut agriculture also plays a vital role in the economy and culture of communities in Indonesia [16]. Knowing the facts, the practice of coconut agriculture in suboptimal land must be implemented in sustainable manners to ensure long-lasting benefit [17].

Currently, drained peatland for agricultural purposes becomes a severe issue on higher carbon emission. The sources of emission are not only from peatland oxidation but also generated by peatland fires. In natural condition, peatland soil is permanently wet under the high water table. The wet condition maintains high carbon stock and prevents carbon loss on peatland soil. The knowledge of the carbon loss from agricultural activities in peatland is fragmented. Long-term observation of carbon loss is needed to overcome the drawback of relatively short studies $(<3 \mathrm{yr})$, especially on the plantation. Hence, proper water management is a crucial part of preventing carbon loss in peatland. The hydrological system is essential to make sustainable management of peatland possible $[18,19]$. Understanding the effect of integrated water resource management to carbon loss also means understanding the sustainability of peatland agricultural activities.

The sustainability principles must consist of environment, social, and economical dimensions. As the purpose of agriculture is to produce food crops, its sustainability should reinforce food security. Indeed, wet peatland can provide ecosystem service to its communities, the challenge is identifying workable ways to minimize the adverse impact of land mismanagement. Pulau Burung District is located in Indragiri Hilir Regency, Riau Province - one of the highest coconut production centre in Indonesia. Most of households in Pulau Burung rely their livelihood on the coconut sector. In the peatland utilization context, the principle is to maintain high productivity of coconut without causing severe environmental degradation, and this involves high water table maintenance to minimize fire risk.

Therefore, in understanding the sustainability of peatland utilization for agriculture, this research aims to analyze strategies to minimize carbon loss in Pulau Burung. Among the strategies, this paper highlighted the integrated water resource management by exploring the result of this practice to global environmental benefit, that is safeguarding the carbon balance. Finally, this study will discuss the practice of minimizing carbon emission that supports sustainability in the area.

\section{Method}

\subsection{Study area}

The study was conducted in the Pulau Burung District, Indragiri Hilir Regency, Riau Province (Figure 1). The study location is in the Sungai Kampar - Sungai Gaung Peatland Hydrological Unit (PHU). The PHU is a peatland ecosystem unit between two rivers or seas that is used by the Indonesian government in managing peatland areas. The Sungai Kampar - Sungai Gaung PHU covers about 711000 ha. Peatland utilization for coconut agriculture on Indragiri Hilir dated back since the early 1900 s on Dutch colonization. A thousand canals were built for coconut harvest transportation. One-tenth coconut area in Indonesia is in Indragiri Hilir.
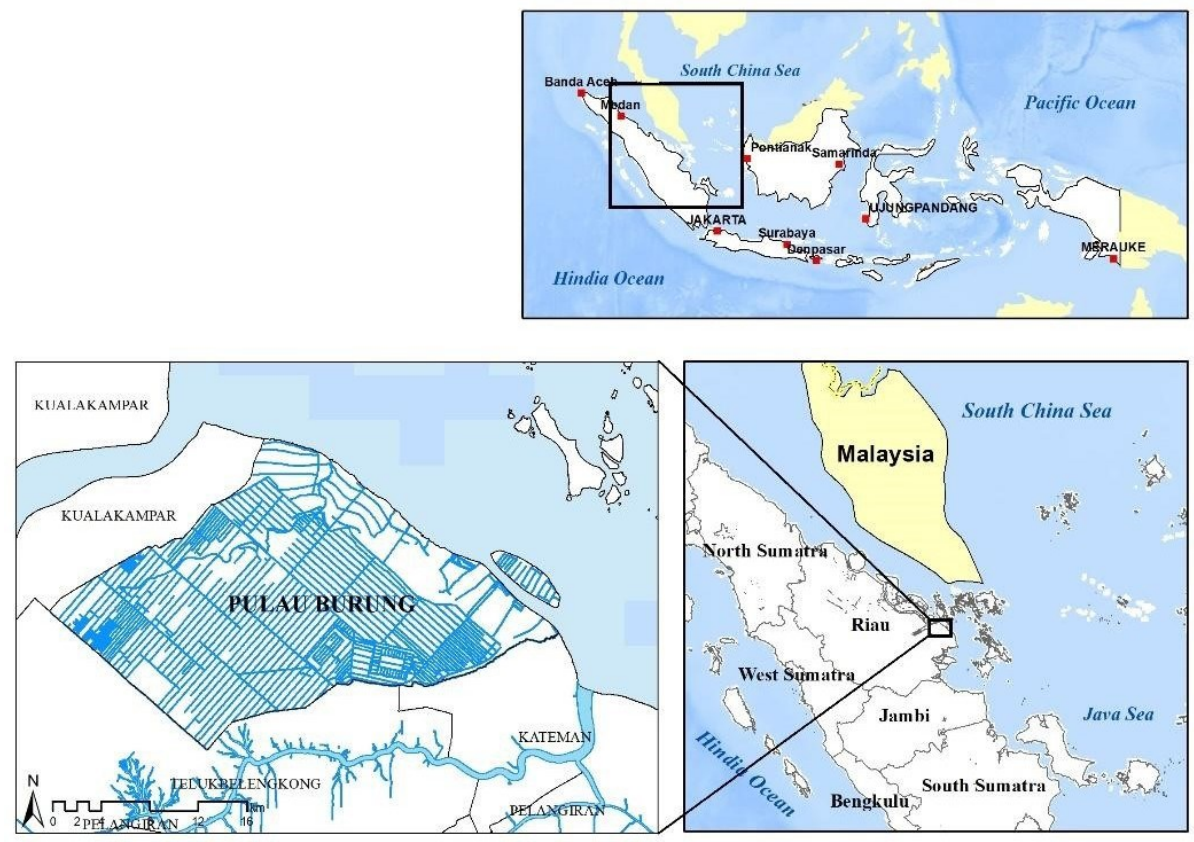

Fig. 1. The map research location in Pulau Burung District, Indragiri Hilir Regency, Riau Province. The blue lines represent the water management network in the area. 
Before the 1990s, Pulau Burung was a name of a single village; however, after becoming the destination of transmigration, this one village grew into several villages and later established into a district. A private entity, namely Sambu Group, acted as an extension of the government. Under the Nucleus Estate SmallholderTransmigration (Perkebunan Inti Rakyat-Trans, PIRTrans) scheme, Sambu Group facilitated practice of the peatland cultivation for coconut and its supply chain. During its initial establishment, this company designed and built the Water Management Trinity (WMT), as an integrated water resource management that functions until now. In the following years, thirteen villages were formed to accommodate the coconut farmer households. These villages were initially called as Satuan Pemukiman (SP), which in later years were developed into definitive (administrative) villages under Pulau Burung District.

\subsection{Data and analysis}

\subsubsection{Water management related data}

The historical water management was obtained for a definite period of time, starting from the initial construction of WMT in Pulau Burung District in 1986. WMT consists of the canal, the dike, also the water gates and the dam. The water management has been managed by the local stakeholders to maintain the water level in the plantation and surrounding area.

In addition, the canal network in the water system plays a vital role in local transportation. Building roads on peatland is difficult because it breaks easily due to subsidence. Therefore, the close system of the canal supports the mobility of the people within the area using the boat. The boat floats on the canal using a ship lock. The canals also become the main transportation to distribute the harvested coconuts and other important commodities for the local community.

Peatland water table depth was recorded from 106 measurement points in 2018 and 2019. The water table measurement was used to monitor water table changes every two weeks. The mean of annual water table depth was calculated from the datasets.

Water management impact on peatland can be seen from its subsidence. Peat subsidence was measured with a $5-\mathrm{cm}$ diameter pole anchored to peat until it reached mineral soil. Subsidence data in four points were recorded every six months since 1986 . The decreasing level of peat surface was measured in $\mathrm{cm}$. The subsidence measurement sites were left undisturbed from harvesting activities. Time-series measurements of subsidence were used to derive a mean subsidence rate yearly.

\subsubsection{Analysis on carbon balance}

Peatland is carbon-rich soil that retains under high water table condition. The change in its water table affects its carbon balance since the water table governs peatland subsidence rate. Lower water table results in higher subsidence rate and therefore higher carbon loss. Carbon loss in peatland consists of emission from fires and peat oxidation. Fire occurrence data was collected from incident data based on reports recorded by Sambu Group and interviews with the local community. Carbon loss from peat oxidation collected from a subsidence-based method. In this research, subsidence rate is used to estimate the carbon loss, which was calculated as follow:

$$
\mathrm{Ec}=\mathrm{Cd} \times \mathrm{S}
$$

where $\mathrm{Ec}$ is carbon emission in $\left(\mathrm{kg} \mathrm{m}^{-3}\right), \mathrm{Cd}$ is carbon density, and $\mathrm{S}$ is subsidence data from measurement $(\mathrm{cm})$.

The basic equation to obtain $\mathrm{Cd}$ is a product of bulk density $\left(\mathrm{BD}, \mathrm{t} \mathrm{m}^{-3}\right)$ and carbon concentration $(\% \mathrm{C})$, which both need laboratory analysis using soil samples from the research study area. Due to the capacity of Sambu Group's

laboratory, this study used the equation described by Warren et al. (2012) to obtain Cd, which used the linear relationship to obtain Cd only using bulk density [20]. The equation is as follow:

$$
\mathrm{Cd}=\mathrm{BD} \times 468.76+5.82
$$

To obtain BD, this study collected soil sampling at sixteen locations in varied peat soil depth, with classification $100 \mathrm{~cm}$ to $200 \mathrm{~cm}, 201 \mathrm{~cm}$ to $300 \mathrm{~cm}$, $301 \mathrm{~cm}$ to $400 \mathrm{~cm}, 401 \mathrm{~cm}$ to $500 \mathrm{~cm}, 501 \mathrm{~cm}$ to $600 \mathrm{~cm}$, and $601 \mathrm{~cm}$ to $700 \mathrm{~cm}$. After measuring the average BD, Ec is calculated using Eq. 1. The carbon (C) in the result is then converted to carbon dioxide $\left(\mathrm{CO}_{2}\right)$ with a conversion factor 3.67.

Further, this study collects similar studies of peatland cultivation and compares the characteristics of the water table, subsidence, and carbon loss.

\section{Result}

\subsection{Regulating water table on peatland utilization}

Several methods can be implemented to maintain a high water table. Peatland agriculture in Pulau Burung applies an integrated water resource management using WMT, locally known as trio tata air, which is a close system to regulate water using the three components: canal, dike, and dam with watergate (Figure 2). WMT was built since the beginning of the plantation operation in 1986. The canal's length is $8000 \mathrm{~km}$ in total and stores $25 \times 10^{6} \mathrm{~m}^{2}$ of fresh peatland water. While the dam and canal are connected to control and store water, the dike is utilized as a technical method to prevent erosion on the canal.

Essentially, WMT has three main benefits to sustainability. First, the system maintains a high water table using the watergate which results in a lower subsidence rate. Second, the dam with the watergate serves to ensure the water inside the canal is at a favourable water table level. By maintaining the water level, not only the water requirement for crop production is fulfilled, it also enables the water storage function all year long. Third, WMT acts as a buffer to prevent floods during the rainy season, next to drought and fire during the dry season. When necessary, the gate will release water to prevent flooding. Otherwise, the water gates are used to keep the water resources. 


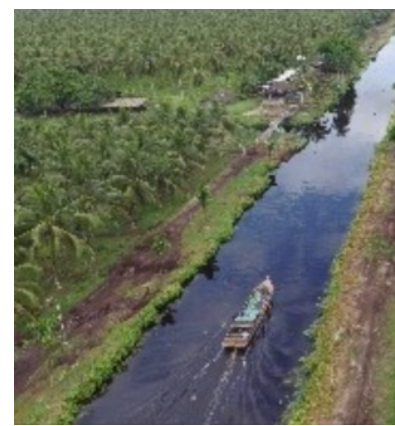

(a)

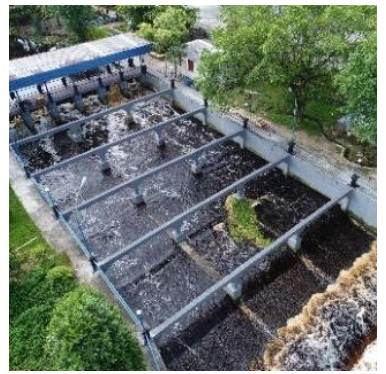

(c) (b)

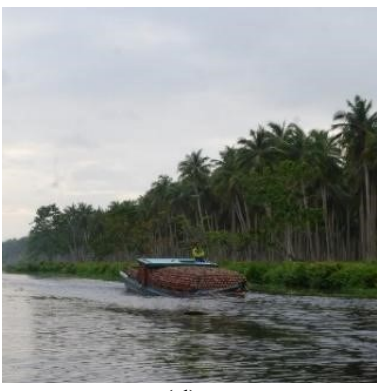

(d)

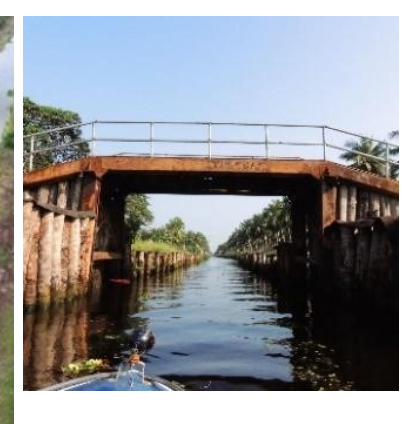

Fig. 2. The three components of the water management system - (a) canal, (b) dike, (c) watergate, where (d) the

The WMT system has maintained the water table to be around $31 \mathrm{~cm}$ to $72 \mathrm{~cm}$ with variability as presented in Figure 3. On yearly average, the mean water table is 48 $\mathrm{cm}$ and $49 \mathrm{~cm}$ in 2018 and 2019, respectively. This water table in Pulau Burung is higher than other plantations that have been recorded (Table 1). In the rainy season, the water table is around $30 \mathrm{~cm}$ to $40 \mathrm{~cm}$ below the surface. During the dry season, it is controlled not to exceed $70 \mathrm{~cm}$. In August to September 2019, Indonesia experienced a rather severe drought due to the ENSO event. During this period, WMT made the lowest water table at $72 \mathrm{~cm}$ that only lasted for two weeks. After that, the water table regulated back on its optimum depth.

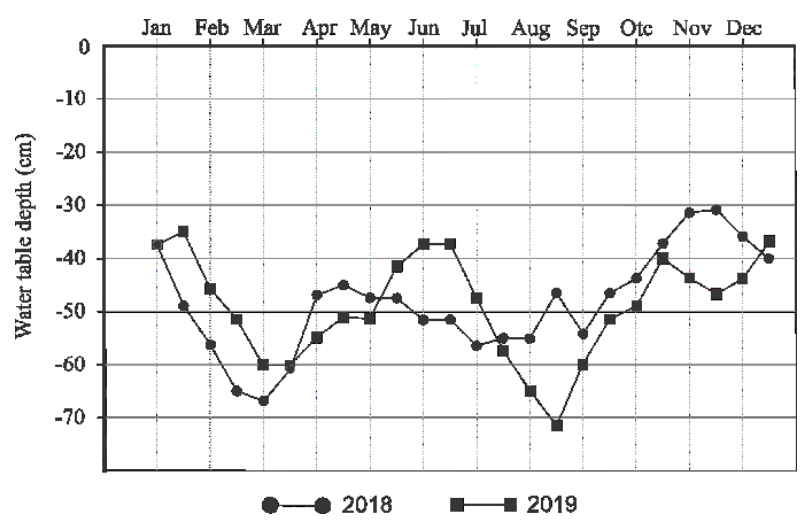

Fig. 3. Water table depth record in 2018 and 2019.

\subsection{Impact of integrated water resource management on peatland subsidence}

The measurement of subsidence in Pulau Burung's plantation from 1986 to 2019 indicated the average subsidence rate of $1.7 \mathrm{~cm} \mathrm{yr}^{-1}$. Cumulative subsidence over this respective $32 \mathrm{yr}$ is recorded at $54.1 \mathrm{~cm}$.

Besides from field measurement, subsidence rate can also be approached from water table depth. Low rate of subsidence is a product of water management that maintains a high mean of water table on plantation [21]. Wösten \& Ritzema (2001) explained the relationship between the water table and subsidence rate with equation $0.04 *$ depth of water table in centimetre [22]. Using the mean water table in 2019, the obtained subsidence rate is $1.96 \mathrm{~cm} \mathrm{yr}^{-1}$ - higher than the actual measurement using the poles.

The significant correlation between water table depth and subsidence in peatland is more evident in a longerterm $[9,23]$. In drained peatland, the first years would record a significant amount of subsidence. Wösten \& Ritzema (2001) estimate after two years of drained peatland the subsidence up to one meter $\left(47 \mathrm{~cm} \mathrm{yr}^{-1}\right)$, and stabilize at $5 \mathrm{~cm} \mathrm{yr}^{-1}$ in following years [22]. Hooijer et al. (2012) also recorded the first year's subsidence of $75 \mathrm{~cm}$, and $19 \mathrm{~cm} \mathrm{yr}^{-1}$ in the following four years [24]. After five years, the subsidence rate is stable in numbers

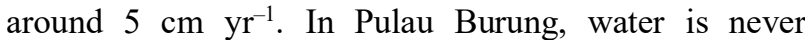
drained since WMT is designed to regulate the water resource. This made the average subsidence rate of 3.3 $\mathrm{cm} \mathrm{yr}^{-1}$ in the first $5 \mathrm{yr}$, with cumulative of

$14.3 \mathrm{~cm}$ between 1986-1991 (Figure 4).

The subsidence component usually consists of $50 \%$ to $92 \%$ from peat oxidation and the rest from compaction. Ishikura et al. (2018) found peat oxidation in oil palm plantations contribute to $72 \%$ to $74 \%$ of total subsidence [25]. Different results were shown by Hooijer et al. (2011) where after 18 yr of drainage, peat oxidation contributed to $92 \%$ of subsidence [26]. While this study cannot extract the percentage of oxidation and compaction from the subsidence, hypothetically, the subsidence rate is mostly from the compaction of peat soil. The WMT as a closed system acts as the water storage in the peat ecosystem makes the rate of oxidation is low. Introducing dams in the canal networks is also one of the effective methods to re-wetting and restore the drained peatland [21].

\subsection{Managing carbon balance by managing water resource}

All agriculture activities produce carbon emission; onefourth global emission is from the agriculture sector. However, this carbon loss can be minimized using various approaches. The WMT has shown successfully suppress fire incident into zero and confirmed from interview result. The only carbon loss sources in Pulau Burung's is from subsidence. Higher subsidence rate in peatland means higher carbon emission.

The average of bulk density in the study area is obtained at $0.15 \mathrm{t} \mathrm{m}^{-3}$; hence the Cd obtained from Eq. 2 is $76.13 \mathrm{~kg} \mathrm{~m}^{-3}$. Coupled with subsidence data, the result of Eq. 1 which describes carbon loss from coconut agriculture in Pulau Burung's peatland is $47.5 \mathrm{Mg} \mathrm{CO}_{2} \mathrm{ha}^{-}$ ${ }^{1} \mathrm{yr}^{-1}$. 


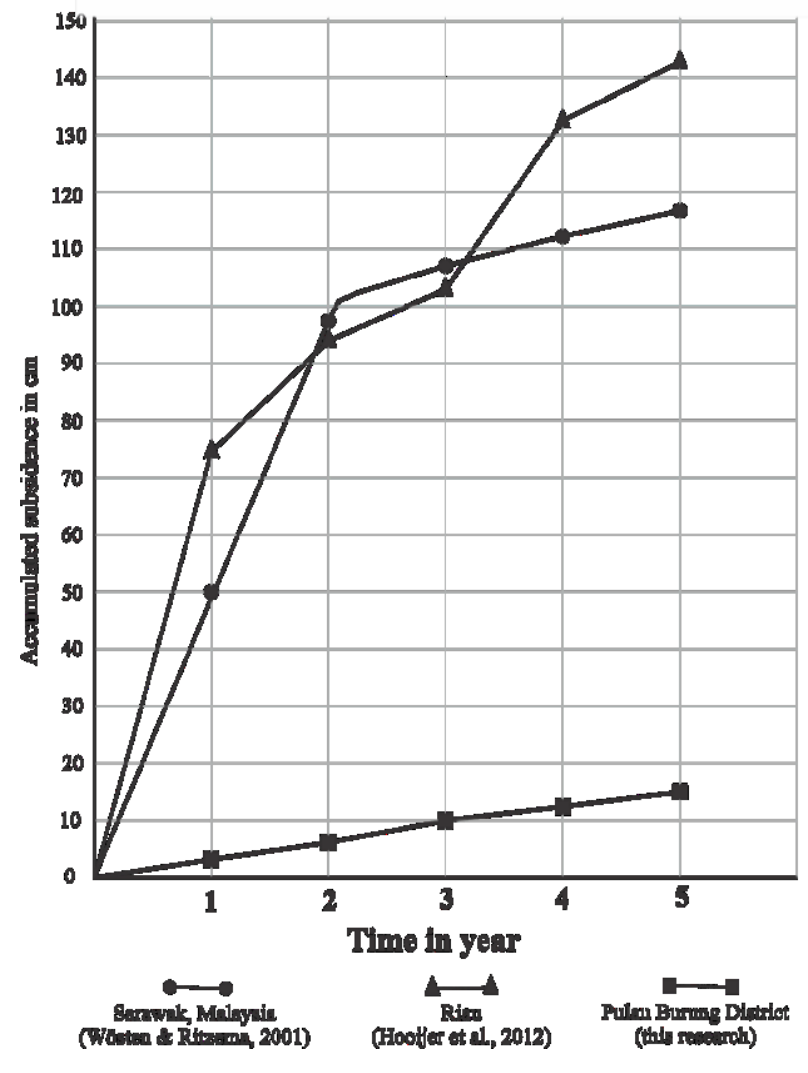

Fig. 4. The accumulated subsidence rate in three different regions of peatland.

For comparison, this study calculates carbon emission using approaches from other studies. Wösten \& Ritzema (2001) explain that every centimeter peat subsidence produces $13 \mathrm{Mg} \mathrm{CO} \mathrm{ha}^{-1} \mathrm{yr}^{-1}$ [22]. Applying this approach to average subsidence of Pulau Burung, this study obtained carbon emission of $22 \mathrm{Mg} \mathrm{CO}_{2} \mathrm{ha}^{-1} \mathrm{yr}^{-1}$. Meanwhile, Hooijer et al. (2010) find a linear relation that lowering $10 \mathrm{~cm}$ of the mean water table will result in an emission rate of $9.1 \mathrm{Mg} \mathrm{CO}_{2} \mathrm{ha}^{-1} \mathrm{yr}^{-1}$ [10]. Applying this approach to the mean water table in 2019, this study obtains $44.59 \mathrm{Mg} \mathrm{CO}_{2} \mathrm{ha}^{-1} \mathrm{yr}^{-1}$ - which corresponds with the result of this paper's calculation.

Table 1 shows that the subsidence in Pulau Burung is the lowest compared to other plantations in peat soil. A study from Evans et al. (2019) showed that the subsidence rate on oil palm plantations was 1.6 to $4.3 \mathrm{~cm} \mathrm{yr}^{-1}$ with mean rate of $3.4 \mathrm{~cm} \mathrm{yr}^{-1}$ [9]. Simultaneously, the same study obtained a subsidence rate on Acacia plantation, which was $5 \mathrm{~cm} \mathrm{yr}^{-1}$. Hooijer et al. (2012) found the subsidence rate in Acacia and oil palm plantation remained constant at around $5 \mathrm{~cm} \mathrm{yr}^{-1}$ after five years of establishment [24]. In a large ecosystem of peatland, the drainage used for agriculture also affects the remnant peatland forest in the vicinity. When there is disruption such as in the form of plantation establishment, the forest near the plantation can have a subsidence rate of $1.8 \mathrm{~cm} \mathrm{yr}^{-1}$ [27]. The subsidence rate in peatland forests

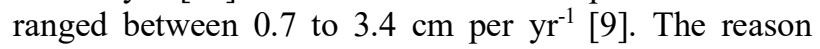
behind this is because peatland is a complex connected ecosystem [28].
Furthermore, carbon emission from coconut agriculture in Pulau Burung is also the lowest compared to emission from other cultivated areas. In Table 1, carbon emissions from oil palm plantations are ranging between 109 - 146.8 $\mathrm{Mg} \mathrm{CO}_{2} \mathrm{ha}^{-1} \mathrm{yr}^{-1}[24,26,27,29]$. In rubber plantation, the carbon emission is $79.1 \mathrm{Mg}$ $\mathrm{CO}_{2} \mathrm{ha}^{-1} \mathrm{yr}^{-1}$ [27]. In Acacia plantation, the carbon emission is higher compared to oil palm and rubber plantations, ranging between $94-261 \mathrm{Mg} \mathrm{CO}_{2} \mathrm{ha}^{-1} \mathrm{yr}^{-1}$ $[10,26,29,30]$. Another research shows that converting peat forest into oil palm plantation oil can generate $59.4 \pm 10.2 \mathrm{Mg} \mathrm{CO}_{2} \mathrm{ha}^{-1} \mathrm{yr}^{-1}$ during the first 25-yr[31].

Besides using the water table and subsidence approaches, there are studies using closed chamber $\mathrm{CO}_{2}$ flux measurements for retrieving carbon emission in peatland. Jauhiainen et al. (2012) found annual $\mathrm{CO}_{2}$ emission is $94 \mathrm{Mg} \mathrm{CO}_{2} \mathrm{ha}^{-1} \mathrm{yr}^{-1}$ with $80 \mathrm{~cm}$ of water table depth [30]. Ali et al. (2006) found the carbon emission in an agriculture area with mean water table depth of $78 \mathrm{~cm}$ is $77 \mathrm{Mg} \mathrm{CO}_{2} \mathrm{ha}^{-1} \mathrm{yr}^{-1}$ [32]. Simultaneously, Comeau et al. (2013) found the emission in an oil palm plantation with water table depth at $76 \mathrm{~cm}$ is $104 \mathrm{Mg} \mathrm{CO}_{2} \mathrm{ha}^{-1} \mathrm{yr}^{-1}$ [33]. In both subsidence-based and $\mathrm{CO}_{2}$ flux methods, water table depth governs carbon emission.

Hence, sustainability of peatland utilization is defined by its water management. Compared to the annual rate of carbon emission from other areas in Table 1, the water management in Pulau Burung has prevented carbon loss around (30 to 200) $\mathrm{Mg} \mathrm{CO} \mathrm{ha}^{-1} \mathrm{yr}^{-1}$. The cumulative carbon loss during $32 \mathrm{yr}$ of coconut agriculture in Pulau Burung is $1511.6 \mathrm{Mg} \mathrm{CO}_{2} \mathrm{ha}^{-1}$ - which is low compared to carbon loss in $25 \mathrm{yr}$ of oil palm and acacia plantations that range between $2088 \mathrm{Mg} \mathrm{CO}_{2} \mathrm{ha}^{-1}$ to $4925 \mathrm{Mg}$ $\mathrm{CO}_{2}$ ha $^{-1}$ [28]. In comparison to drained peatland mentioned in Wösten \& Ritzema (2001), WMT in Pulau Burung has prevented carbon loss up to $2870 \mathrm{Mg} \mathrm{CO}_{2}$ $\mathrm{ha}^{-1}$ in the first $5 \mathrm{yr}$ [22]. These numbers highlight the crucial role of an integrated water resource management in peatland. Instead of draining water, proper management regulates the water resource which leads to minimize the subsidence and carbon loss.

\section{Discussion}

Peatland agriculture tends to be unsustainable because the necessity to drain and lower the water table to a level that is suitable for the crop to grow. As a result, the area releases more $\mathrm{CO}_{2}$ to the atmosphere from land subsidence and makes the area susceptible to fires. The relationship between subsidence and carbon emission is derived from the peat oxidation process. When the peatland is drained or with high water table depth, the emission is higher. Another source of emission of peatland comes from the forest fire. This condition is exacerbated by poor management and dry peat soil where the practice of purposely burning the area to clear the peatland for agriculture still occurs. 
Table 1. List of estimated subsidence rate, average water table, and carbon emission in various plantations in peatland regions.

\begin{tabular}{|l|l|c|c|c|c|c|}
\hline \multicolumn{1}{|c|}{ Crop type } & \multicolumn{1}{|c|}{ Location } & $\begin{array}{c}\text { Year of } \\
\text { recorded } \\
\text { data }\end{array}$ & $\begin{array}{c}\text { Average } \\
\text { subsidence } \\
\left(\mathrm{cm} \mathrm{year}^{-1}\right)\end{array}$ & $\begin{array}{c}\text { Mean } \\
\text { water table } \\
\text { depth (cm) }\end{array}$ & $\begin{array}{c}\text { Carbon } \\
\text { Emission } \\
\left(\mathrm{Mg} \mathrm{CO}_{2} \text { ha }^{-1}\right. \\
\left.\text { year }^{-1}\right)\end{array}$ & Source \\
\hline Oil palm & $\begin{array}{l}\text { Tanjung Jabung Barat } \\
\text { Regency, Jambi }\end{array}$ & - & 4.7 & - & 121 & {$[27]$} \\
\hline Oil palm & Jambi & 18 & 5.4 & 70 & 119 & {$[24]$} \\
\hline Oil palm & Central Kalimantan & 25 & 3.5 & $60-80$ & 147 & {$[29]$} \\
\hline Oil palm & Jambi & 7 & - & 76 & 104 & {$[33]$} \\
\hline Rubber & Tanjung Jabung Barat & $>30$ & 2.7 & - & 79 & {$[27]$} \\
\hline Acacia & Cegency, Jambi & 25 & 6.8 & $80-100$ & 261 & {$[29]$} \\
\hline Acacia & Riau & 6 & 5.0 & 70 & 178 & {$[24]$} \\
\hline Acacia & Kampar Peninsula, Riau & - & - & 80 & 94 & {$[30]$} \\
\hline Settled agriculture & Jambi Province & - & - & 80 & 77 & {$[32]$} \\
\hline Coconut & $\begin{array}{l}\text { Tanjung Jabung Barat } \\
\text { Regency, Jambi }\end{array}$ & $>40$ & 2.8 & - & 85 & {$[27]$} \\
\hline Coconut & Indragiri Hilir, Riau & 32 & 1.7 & 49 & 47.5 & $\begin{array}{c}\text { This } \\
\text { research }\end{array}$ \\
\hline
\end{tabular}

Notes: (-) means the data is unavailable in the source research.

The key to minimize the detrimental effect of peatland agriculture lies in the water management to keep the peat soil wet. Not only preventing higher subsidence and fire risk, it also regulates water flows to minimize the risk of flooding, drought, and seawater intrusion - if the peat region is located near a coastal area.

The case with WMT existence in Pulau Burung reveals some correlations among the ecosystem components. Firstly, the measurement showed that in the long dry season especially influenced by ENSO, the water table is lower. Yet, the water management is able to regulate the depth back to its optimum level. In fact, Indonesia has experienced severe forest fires almost every year when there is a long dry season or year with a strong effect of ENSO. It is often combined with the slash and burn activity for agriculture development, which worsen the fire spread.

It is interesting to note that based on the available data, no major wildfire occurred within and near the plantation area since the establishment of water management trinity during the initial development phase in Pulau Burung. The function of the canal is to store water, which implies higher soil moisture up to $90 \%$. Soil moisture is crucial to resist forest fire, especially in peatland [34].

To reduce carbon emission and to ensure the responsible peatland utilization practice, there are three parameters of sustainable use [35]. From an environmental perspective, any practice related to peatland should involve conservation values and prevent its degradation. The relevant stakeholders who wish to utilize peatland should comprehend the sponge-like characteristics of peatland that requires an advanced water management system. Conserving and preventing peatland degradation can be measured with the absence of flood, drought, subsidence, wildfire, and high carbon release. With no report of significant fire incidents, next to flooding and drought from the local people in Pulau
Burung, the agriculture practice that is safeguarded by WMT is in line with sustainable principles.

To this end, the authority should formulate regulations that accommodate the variety of peatland characteristics and utilizations. The Government of Indonesia has issued a regulation No. 57/2016 about peatland management, which requires maintaining a mean water table maximum $40 \mathrm{~cm}$ below the surface, in particular, to reduce the risk of peat fire and its spread. Based on the regulation, if the water table exceeds $70 \mathrm{~cm}$, it is categorized as the damaged ecosystem. The water table level around $40-70 \mathrm{~cm}$ is still acceptable due to seasonal change. The challenge is that this water table should also conform to the water requirement for crop growth. This again highlights the crucial role of an integrated water resource management.

Meanwhile, from the human point of view, any practice must consider and support the local communities in adopting sustainable peatland agriculture. In many peatland regions, people have settled in the area for a long time. Responsible peatland agriculture should adopt the knowledge derived from the local, next to give more benefits to them. The relevant stakeholders need to realize that the impact of sustainable peatland utilization contributes to the lifespan of peatland itself. Higher subsidence in drained peatland can decrease the lifespan of peatland to $30 \mathrm{yr}$ to $55 \mathrm{yr}$ [29] - which means a decreasing opportunity for a sustainable peatland cultivation.

The local households in Pulau Burung District rely their livelihood on coconut farming. They are aware that it is important to conserve peat soil and maintain a high water table since they experience the benefits of the two aspects themselves. Therefore, the local community is the most prominent actor and the key to the sustainable use of peatland. The local community knowledge plays a big role in sustainable use both from the environment and socio-economic perspectives. 


\section{Conclusion}

Low subsidence rate made the peatland utilization can prevent annual carbon loss around $30 \mathrm{Mg} \mathrm{CO}_{2} \mathrm{ha}^{-1} \mathrm{yr}^{-1}$ to $200 \mathrm{Mg} \mathrm{CO}_{2} \mathrm{ha}^{-1} \mathrm{yr}^{-1}$. The sustainable use of peatland must conserve and prevent degradation in peatlands. This study found water management is vital to ensure low carbon emission in a peatland agriculture practice. WMT in Pulau Burung maintains the water table to be around $31 \mathrm{~cm}$ to $72 \mathrm{~cm}$ with yearly average of $48 \mathrm{~cm}$ to $49 \mathrm{~cm}$ which contributes to low subsidence and carbon emission. In Pulau Burung, the integrated water resource management also contributes to the other aspect of sustainability - the people. The thriving livelihood in Pulau Burung shows that water management not only contributes to the minimum environment degradation but also benefits the people. When the locals understand the benefits, they can commit to safeguard the peatland as well. Therefore, the local community also needs to be involved in implementing the practice.

\section{References}

1. J. Xu, P. J. Morris, J. Liu, and J. Holden, Catena 160 , 134 (2018)

2. C. M. Finlayson and G. R. Milton, in Wetl. B. II Distrib. Descr. Conserv. (Springer Nature, 2018), pp. 227-244

3. M. Warren, K. Hergoualc'h, J. B. Kauffman, D. Murdiyarso, and R. Kolka, Carbon Balance Manag. 12, 1 (2017)

4. M. R. Turetsky, B. Benscoter, S. Page, G. Rein, G. R. Van Der Werf, and A. Watts, Nat. Geosci. 8, 11 (2015)

5. J. Ghazoul, Z. Burivalova, J. Garcia-Ulloa, and L. A. King, Trends Ecol. Evol. 30, 622 (2015)

6. K. L. Bacon, A. J. Baird, A. Blundell, M. A. Bourgault, P. J. Chapman, G. Dargie, G. P. Dooling, C. Gee, J. Holden, T. Kelly, K. A. McKendrickSmith, P. J. Morris, A. Noble, S. M. Palmer, A. Quillet, G. T. Swindles, E. J. Watson, and D. M. Young, Mires Peat 19, (2017)

7. D. A. Fadhillah Hafni, L. Syaufina, N. Puspaningsih, and I. Prasasti, in IOP Conf. Ser. Earth Environ. Sci. (Institute of Physics Publishing, 2018)

8. S. E. Page, F. Siegert, J. O. Rieley, H. D. V. Boehm, A. Jaya, and S. Limin, Nature 420, 61 (2002)

9. C. D. Evans, J. M. Williamson, F. Kacaribu, D. Irawan, Y. Suardiwerianto, M. F. Hidayat, A. Laurén, and S. E. Page, Geoderma 338, 410 (2019)

10. A. Hooijer, S. Page, J. G. Canadell, M. Silvius, J. Kwadijk, H. Wösten, and J. Jauhiainen, Biogeosciences 7, 1505 (2010)

11. A. M. Hoyt, E. Chaussard, S. S. Seppalainen, and C. F. Harvey, Nat. Geosci. 13, 435 (2020)

12. J. Couwenberg and A. Hooijer, Mires Peat 12, 1 (2013)

13. FAO, IFAD, UNICEF, WFP, and WHO, The State of Food Security and Nutrition in the World 2019.
Safeguarding against Economic Slowdowns and Downturns (Food and Agriculture Organization of the United Nations, Rome, 2019)

14. J. van Vliet, Nat. Sustain. 2, 755 (2019)

15. A. Surahman, P. Soni, and G. P. Shivakoti, J. Integr. Environ. Sci. 15, 1 (2018)

16. P. Rethinam, in Coconut Palm (Cocos Nucifera L.) Res. Dev. Perspect., edited by K. U. K. Nampoothiri (Springer Nature Singapore, Gateway East, Singapore, 2018), pp. 21-56

17. A. N. Rahmasary, N. Fajri Usman, I. Zahara Qurani, T. J. Foundation, J. Rawa, B. Utara, and N. 26, E3S Web Conf. 142, 03005 (2020)

18. S. Evers, C. M. Yule, R. Padfield, P. O'Reilly, and H. Varkkey, Glob. Chang. Biol. 23, 534 (2017)

19. M. E. Harrison, J. B. Ottay, L. J. D'Arcy, S. M. Cheyne, Anggodo, C. Belcher, L. Cole, A. Dohong, Y. Ermiasi, T. Feldpausch, A. Gallego-Sala, A. Gunawan, A. Höing, S. J. Husson, I. P. Kulu, S. M. Soebagio, S. Mang, L. Mercado, H. C. MorroghBernard, S. E. Page, R. Priyanto, B. Ripoll Capilla, L. Rowland, E. M. Santos, V. Schreer, I. N. Sudyana, S. B. B. Taman, S. A. Thornton, C. Upton, S. A. Wich, and F. J. F. Veen, People Nat. 2, 4 (2020)

20. M. W. Warren, J. B. Kauffman, D. Murdiyarso, G. Anshari, K. Hergoualc'H, S. Kurnianto, J. Purbopuspito, E. Gusmayanti, M. Afifudin, J. Rahajoe, L. Alhamd, S. Limin, and A. Iswandi, Biogeosciences 9, 4477 (2012)

21. H. Ritzema, S. Limin, K. Kusin, J. Jauhiainen, and H. Wösten, Catena 14, 11 (2014)

22. J. H. M. Wösten and H. P. Ritzema, Int. Peat J. 59 (2001)

23. R. W. Nusantara, R. Hazriani, and U. E. Suryadi, IOP Conf. Ser. Earth Environ. Sci. 145, 012090 (2018)

24. A. Hooijer, S. Page, J. Jauhiainen, W. A. Lee, X. X. $\mathrm{Lu}, \mathrm{A}$. Idris, and G. Anshari, Biogeosciences 9, 1053 (2012)

25. K. Ishikura, T. Hirano, Y. Okimoto, R. Hirata, F. Kiew, L. Melling, E. B. Aeries, K. S. Lo, K. K. Musin, J. W. Waili, G. X. Wong, and Y. Ishii, Agric. Ecosyst. Environ. 254, 202 (2018)

26. A. Hooijer, S. Page, J. Jauhiainen, W. A. Lee, X. X. Lu, A. Idris, and G. Anshari, Biogeosciences Discuss. 8, 9311 (2011)

27. N. Khasanah and M. van Noordwijk, Mitig. Adapt. Strateg. Glob. Chang. 24, 147 (2019)

28. D. Astiani, B. Burhanuddin, L. M. Curran, M. Mujiman, and R. Salim, Indones. J. For. Res. 4, 15 (2017)

29. J. O. Rieley and S. E. Page, in Proc. 13th Int. Peat Congr., edited by J. Feehan and C. A. Farrel (Tullamore, Ireland, 2008), pp. 246-249

30. J. Jauhiainen, A. Hooijer, and S. E. Page, Biogeosciences 9, 617 (2012) 
31. D. Murdiyarso, K. Hergoualc'H, and L. V. Verchot, Proc. Natl. Acad. Sci. U. S. A. 107, 19655 (2010)

32. M. Ali, D. Taylor, and K. Inubushi, Wetl. 2006262 26, 612 (2006)

33. L.-P. Comeau, K. Hergoualc', J. U. Smith, and L. Verchot, Conversion of Intact Peat Swamp Forest to Oil Palm Plantation Effects on Soil CO 2 Fluxes in Jambi, Sumatra. Working Paper 110 (Bogor, Indonesia, 2013)

34. N. C. Dadap, A. R. Cobb, A. M. Hoyt, C. F. Harvey, and A. G. Konings, Environ. Res. Lett. 14, 094014 (2019)

35. H. Joosten, M.-L. Tapio-Biström, and S. Tol, Peatlands - Guidance for Climate Change Mitigation through Conservation, Rehabilitation and Sustainable Use (Food and Agriculture Organization, Rome, Italy, 2012)

36. K. Hergoualc'H and L. V. Verchot, Global Biogeochem. Cycles 25, (2011) 